\title{
ALAT PEMBERI MAKAN KUCING OTOMATIS BERBASIS ARDUINO UNO PADA PET SHOP
}

\author{
Ummul Khair ${ }^{1)}$ dan Tiara Sabrina ${ }^{2)}$ \\ ${ }^{1,2}$ Teknik Informatika, Fakultas Teknik dan Komputer, Universitas Harapan Medan \\ ${ }^{1,2}$ Jl. Imam Bonjol No. 35 Medan \\ E-mail : ummul.kh@gmail.com ${ }^{1)}$, tiarasbrn03@gmail.com ${ }^{2)}$
}

\begin{abstract}
ABSTRAK
Pet Shop adalah tempat atau perusahaan yang bergerak di bidang penjualan hewan peliharaan. Selain menjual hewan peliharaan, pet shop juga menjual makanan hewan peliharaan serta menerima jasa penitipan dan perawatan hewan peliharaan. Dalam pemberian makan hewan peliharaan yang dititipkan di Pet Shop umumnya masih memakai cara konvensional dalam pemberian makanan pada hewan. Sehingga pet shop harus membutuhkan tenaga karyawan lepas hanya untuk memberi makan dan perawatan lain, juga tidak disediakan takaran makanan yang tepat bagi hewan peliharaan. Hal ini menyebabkan dampak negatif bagi kesehatan dan mental hewan peliharaan dalam kasus ini adalah kucing. Untuk itu dibutuhkan suatu alat pemberian makanan kucing otomatis yang berisikan sensor berat (loadcell) yang memiliki kemampuan mendeteksi berapa berat makanan yang akan dikeluarkan dari tabung. Serta RTC yang mampu menginput waktu makan kucing. Sehingga kucing dapat makan tepat waktu dan sesuai takaran. Dilengkapi juga dengan buzzer sehingga kucing dapat mengetahui waktu makan melalui suara yang dihasilkan oleh buzzer.
\end{abstract}

Kata Kunci: Pet Shop, Pemberi Makan Otomatis, Sensor Berat, Hewan Peliharaan.

\section{PENDAHULUAN}

Makan adalah suatu proses yang penting bagi tubuh. Dengan makan tubuh akan mendapatkan nutrisi sekaligus energi yang dibutuhkan untuk mempertahankan hidup (Salvana 2008). Tidak hanya manusia, hewan juga sangat membutuhkan nutrisi dari makanannya terutama hewan peliharaan. Fokus utama dari pemeliharaan hewan khususnya kucing adalah terletak pada pemberian makanannya.

Seorang pecinta hewan peliharaan dapat menghabiskan banyak uang untuk membeli makanan peliharaannya yang berkualitas. Namun tidak selamanya pecinta kucing memiliki banyak waktu luang sehingga tidak sedikit yang menitipkan hewan peliharaannya di Pet Shop.

Salah satu fasilitas yang disediakan pet shop adalah pemberian makan pada hewan peliharaan yang dititipkan, namun ada beberapa kendala yang dihadapi yaitu tidak adanya takaran yang tepat dalam pemberian makanan pada hewan peliharaan yang dititipkan. Selain itu, permasalahan yang dihadapi oleh pet shop adalah saat jumlah hewan peliharaan yang dititipkan meningkat maka pet shop harus membutuhkan karyawan tambahan untuk membantu dalam perawatan dan pemberian makanan hewan peliharaan yang dititipkan.

Untuk itu dibutuhkan sebuah mekanisme otomatis yang dapat digunakan untuk membantu pet shop dalam pemberian makan kepada hewan peliharaan yang dititipkan sesuai dengan takarannya. Karena khusus hewan kucing pemberian takaran manakan yang tidak sesuai dapat menimbulkan dampak buruk bagi kucing tersebut. Dengan adanya alat pemberian makanan kucing otomatis diharapkan dapat mengatasi masalah yang terjadi pada pet shop yaitu dapat menghemat biaya, mengurangi jumlah karyawan, serta mengefisiensikan pemberian makanan pada hewan peliharaan yang dititipkan.

Perancangan alat pemberi makanan kucing otomatis ini akan menggunakan perangkat Arduino, Sensor Berat (Load Cell), Motor Servo, dan lain sebagainya.

\section{RUANG LINGKUP}

Dalam penelitian ini permasalahan mencakup:

1. Cakupan permasalaahan.

Adapun cakupan permasalahan dalam penelitian ini adalah menciptakan alat untuk membantu pet shop dalam memberikan makan kucing secara otomatis menggunakan perangkat Arduino Uno dan sensor berat.

2. Batasan-batasan penelitian.

Batasan-batasan dalam penelitian ini adalah:

1) Perancangan alat hanya berfokus pada pemberian makan kucing otomatis

2) Perangkat-perangkat yang digunakan antara lain Arduino Uno, Sensor Berat (Load Cell), Motor Servo, dan Modul HX71.

3. Rencana hasil yang didapatkan

Hasil yang diharapkan alat yang dibuat mampu memberikan hasil yang diinginkan yaitu mampu memberikan makanan kepada kucing di pet shop secara otomatis dan sesuai dengan yang diharapkan. 


\section{BAHAN DAN METODE}

Dipaparkan bahan kajian teori dan model penelitian yang berkaitan.

\subsection{Arduino}

Arduino didefinisikan sebagai platform elektronik bersifat open source berbasis perangkat lukan dan keras yang fleksibel dan mudah digunakan dalam membuat objek atau lingkungan yang interaktif (Artanto 2012). Papan Arduino merupakan papan mikrokontroler berukuran kecil yang didalamnya terdapat rangkaian komputer berbentuk chip yang kecil. Mikrokontroler merupakan komputer berukuran kecil yang dapat melakukan pekerjaan layaknya komputer pada umumnya namun dengan kapasitas yang jauh lebih kecil (Kadir 2015). Perangkat utama arduino dapat dilihat pada gambar 1.

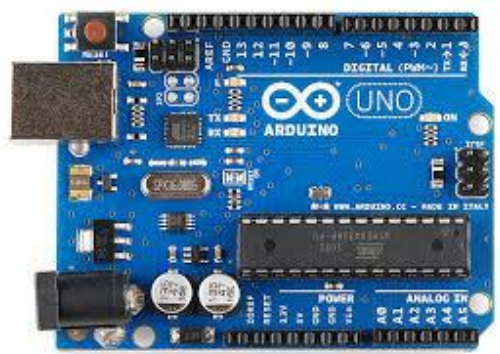

Gambar 1. Perangkat Arduino

\subsection{Sensor Berat (Loadcell)}

Sensor Berat atau Loadcel adalah tranduser yang digunakan untuk mengubah takanan menjadi sinyal elektrik. Biasanya alat ini terdiri dari empat strain gauges dalam wheatstone brigde configuration, tetap ada juga yang terdiri dari satu atau duat strain gauges. Sinyal Output elektri direpresentasikan dalam milivolt dan memerlukan penguatan oleh instrumen amplifier sebelum dapat digunakan (Handajadi and Sholeh 2009). Perangkat Sensor berat dapat dilihat pada Gambar 2.

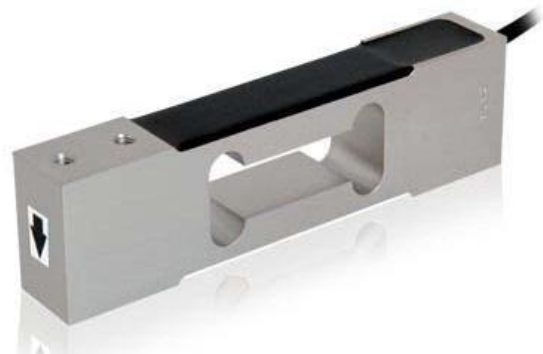

\section{Gambar 2. Sensor Berat (Loadcell)}

\subsection{Modul HX711}

Modul HX711 adalah modul yang memudahkan kita membaca load cell dalam pengukuran berat. Modul ini berfungsi untuk menguatkan sinyal keluaran dari sensor dan mengonversi data analog menjadi data digital dan dihubungkan ke mikrokontroler maka kita dapat membaca perubahan resistansi dari load cell. Setelah proses kalibrasi kita akan memperoleh pengukuran berat dengan keakuratan yang tinggi (Limantara, Chandra and Mudjanarko 2017). Modul HX711 daat dilihat pada Gambar 3.

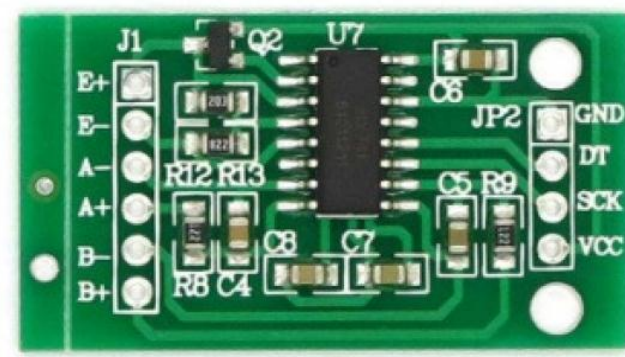

Gambar 3. Modul HX711

\subsection{Motor Servo}

Motor servo adalah sebuah motor dengan sistem closed feedback di mana posisi dari motor akan diinformasikan kembali ke rangkaian kontrol yang ada di dalam motor servo. Motor ini terdiri dari motor dc, rangkaian gear, potensio meter dan rangkaian kontrol (Riza dan Satria 2006). Perangkat motor servo dapat dilihat pada Gambar 4.

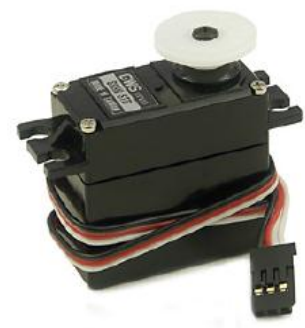

\section{Gambar 4. Motor Servo}

\subsection{Model Penelitian}

Proses pemberian makanan pada hewan yang dititipkan pada Pet shop khususnya kucing masih menggunakan cara yang manual, Jika pegawai perawatan hewan terlambat masuk atau sedang tidak bertugas maka kucing juga akan terlambat diberi makan. Dengan menggunakan alat, proses pemberian makan dapat dilakukan secara otomatis. Ketika waktu makan kucing sudah tiba dimana waktu terlebih dahulu di tentukan pada Real time clock. Maka, alat akan melakukan pengecekan tempat makanan kucing. Dengan menggunakan sensor berat (Loadcell), berat makanan akan terdeteksi. Jika berat makanan pada tempat makanan sudah sesuai dengan berat yang ditentukan, maka alat tidak lagi memberikan makanan.

\subsection{Perancangan Sistem}

Perancangan sistem yang akan dilakukan adalah merancang alat yang digunakan untuk membantu proses pemberian makan pada kucing secara otomatis. Alat ini dilengkapi dengan motor servo yang bekerja otomatis dengan bantuan Real time clock sebagai pengatur waktu yang dibutuhkan untuk membuat servo bekerja sesuai waktu yang telah ditentukan. Selain itu terdapat pula sensor berat (Loadcell) yang dihubungkan dengam module HX711 yang berfungsi menginformasikan berapa berat benda yang ada di atas sensor tersebut. Alat akan mengeluarkan makanan secara otomatis jika waktu yang telah di set terlebih dahulu pada Real time clock pada waktu sebenarnya menunjukkan waktu yang sama, serta tidak ada objek yang terdapat di atas sensor berat (Loadcell). Media pengatur waktu yang digunakan 
adalah Real time clock DS-1302 yang dihubungkan ke Arduino Uno dan di koneksikan pada komputer/laptop menggunakan aplikasi Arduino 1.8.5. Berikut ini adalah
Diagram Proses Sistem yang di tampilkan pada Gambar 5 .

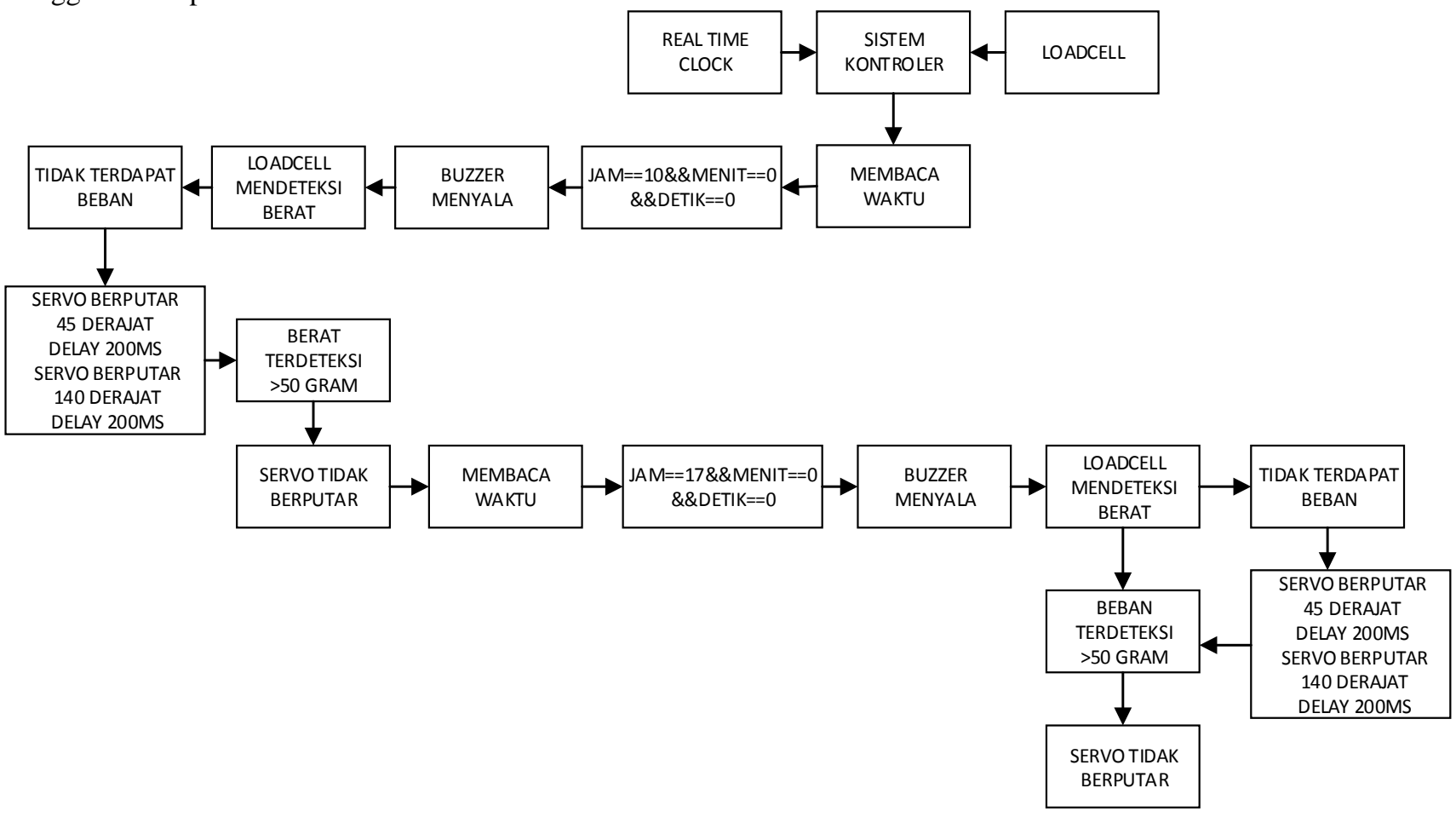

Gambar 5. Diagram Proses Sistem

Proses pemberian makanan kucing secara otomatis diawali dengan memberikan perintah pada Arduino sesuai dengan waktu makan kucing, ketika Real time clock menunjukkan waktu yang sesuai dengan waktu yang telah ditentukan di Arduino maka buzzer akan berbunyi sebagai penanda bahwa waktu makan kucing tiba. Selanjutnya sensor berat (Loadcell) akan mendeteksi berat yang terdapat pada tempat makan kucing, jika berat makanan yang terdapat pada tempat makan kucing lebih kecil atau sama dengan 50 gram maka servo akan bergerak dari 140 derajat ke 45 derajat dengan delay selama 200 mili detik, setelah itu servo akan bergerak lagi dari 45 derajat ke 140 derajat dengan delay selama 200 mili detik. Hal tersebut akan terus berlanjut hingga berat makanan pada tempat tempat makan kucing mencapai 50 gram atau lebih.
Jika kondisi pertama telah berakhir maka Arduino akan menunggu hingga Real time clock menunjukkan waktu kedua yang telah disesuaikan dengan waktu yang telah ditentukan di Arduino jika waktu yang ada pada Real time clock sudah sesuai dengan waktu yang telah ditentukan di Arduino maka buzzer akan berbunyi sebagai penanda bahwa waktu makan kucing tiba. Selanjutnya sensor berat (Loadcell) akan membaca berat yang terdapat pada tempat makan kucing, jika berat makanan yang terdapat pada tempat makan kucing lebih kecil atau sama dengan 50 gram maka servo akan bergerak dari 140 derajat ke 45 derajat dengan delay selama 200 mili detik, setelah itu servo akan bergerak lagi dari 45 derajat ke 140 derajat dengan delay selama 200 mili detik. Hal ini akan terus berulang hingga baterai pada Real time clock habis atau arus yang diberikan pada Arduino Uno terputus. 

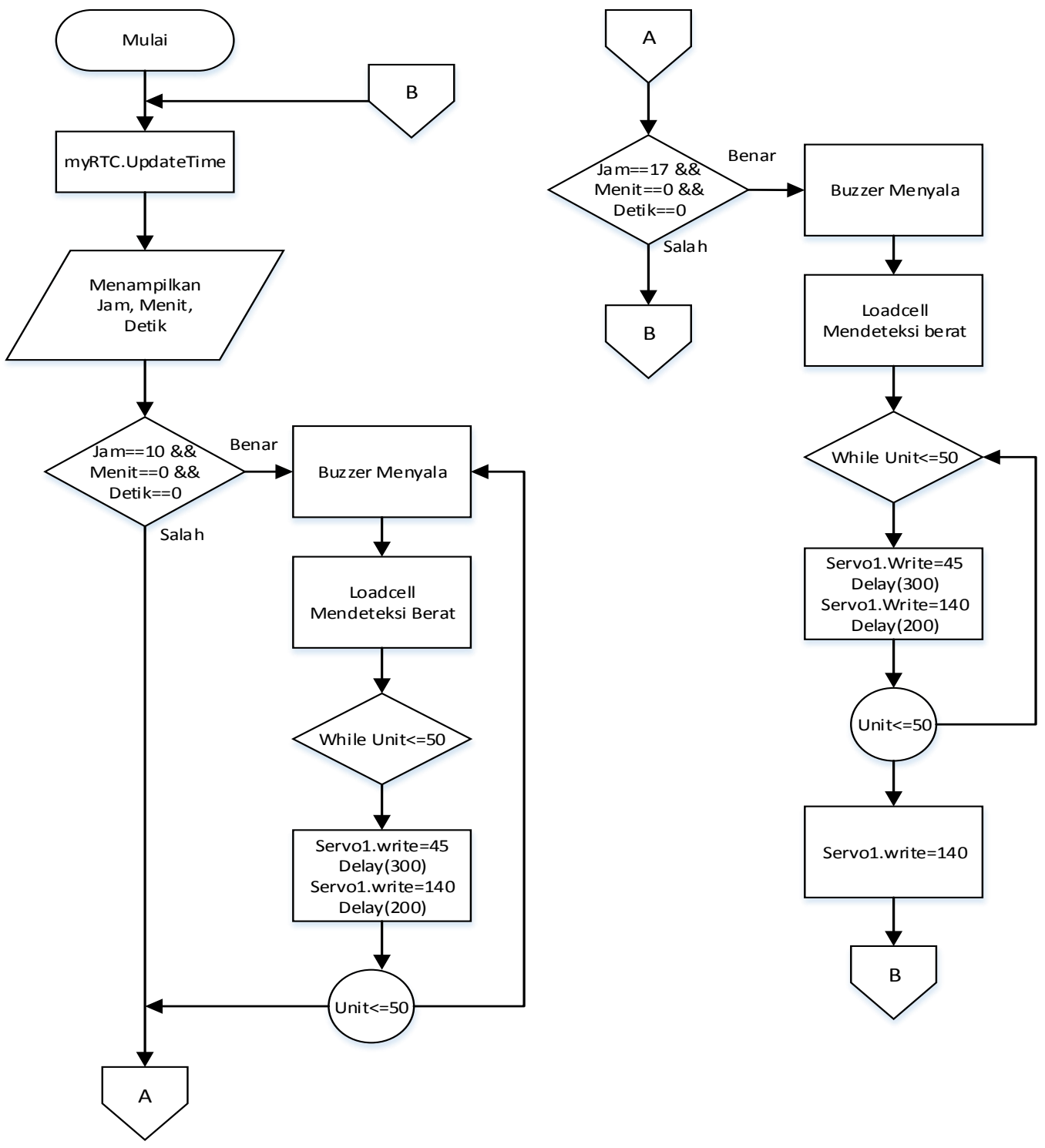

Gambar 6. Flowchart Sistem

\subsection{Perancangan Mekanik}

Pada bagian ini dibahas tentang perancangan masingmasing komponen yang dirangkai menjadi satu kesatuan. Adapun komponen-komponen dalam pembuatan alat ini adalah:

1. Real Time Clock DS1302

2. Sensor Berat (Loadcell)

3. Modul HX711

4. Arduino Uno

5. Motor Servo

6. Buzzer

7. Kabel

8. Tabung Penyimpanan Makanan

9. Case

Dari komponen-komponen diatas akan di rangkai sedemikian rupa sehingga menjadi rangkaian sebagai berikut ini.

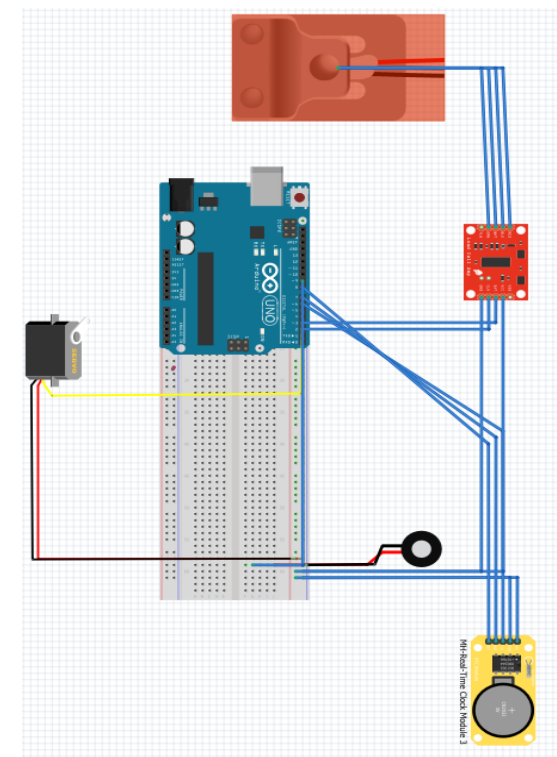

Gambar 7. Rangkaian Keseluruhan Alat 
Untuk mengetahui apakah semua komponen telah berjalan sesuai dengan semestinya maka dilakukan pengujian.

1. Pengujian real time clock DS-1302

Pengujian ini bertujuan untuk mengetahui apakah waktu yang terdapat pada Arduino telah sesuai dengan waktu yang sebenarnya yang dapat dibandingkan dengan waktu yang terdapat pada komputer. Pengujian dilakukan dengan menampilkan Serial Monitor pada program Sketch.

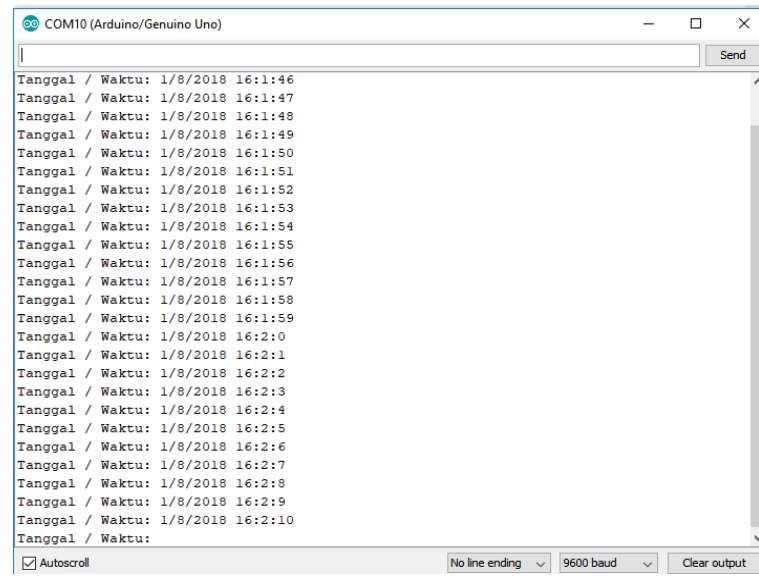

Gambar 8. Pengujian Real Time Clock DS-1302

2. Pengujian Buzzer

Pengujian ini bertujuan untuk mengetahui kinerja Buzzer. Pada alat ini Buzzer berfungsi sebagai penanda waktu makan kucing telah tba. Buzzer akan menyala apabila waktu pada RTC sesuai dengan waktu yang sebenarnya. Setelah dilakukan pengujian, diketahui bahwa Buzzer dapat berfungsi dengan baik. Tabel 1 adalah Pengujian dari Buzzer

Tabel 1. Penugjian Buzzer

\begin{tabular}{cclc}
\hline No & $\begin{array}{c}\text { Keadaan } \\
\text { Buzzer }\end{array}$ & \multicolumn{3}{c}{ Ket. } \\
\hline 1 & Hidup & $\begin{array}{l}\text { Waktu pada RTC menunjukkan } \\
\text { waktu makan kucing }\end{array}$ \\
2 & Mati & $\begin{array}{l}\text { Waktu pada RTC tidak } \\
\text { menunjukkan waktu makan kucing }\end{array}$ \\
\hline
\end{tabular}

3. Pengujian Sensor Berat

Pengujian ini bertujuan untuk mengetahui apakah sensor berat (Loadcell) dapat membaca berat dengan semestinya. Karena itu dilakukan kalibrasi terlebih dahulu. Untuk mendapatkan nilai berat yang akurat.

4. Pengujian Motor Servo

Pengujian ini bertujuan untuk mengetahui kinerja Motor Servo. Pada alat ini servo berfungsi sebagai pemutar tabung penyimpanan makanan kucing sehingga apabila RTC telah menunjukkan waktu makan kucing, Servo akan memutar dan membuka tabung yang berisi makanan. Sehingga makanan dapat keluar secara otomatis. Setelah dilakukan pengujian, diketahui bahwa servo dapat berfungsi dengan baik.
Alat pemberian makanan kucing otomatis dijalankan pada waktu makan kucing yaitu pukul 10.00 dan pukul 17.00. Jika waktu pada RTC menunjukkan waktu yang sama dengan waktu makan yang telah ditentukan tersebut maka Buzzer akan menyala beberapa saat, kemudian servo akan berputar 45 derajat membuka tabung penyimpanan makanan dengan delay 200 mili detik kemudian berputar kembali 140 derajat menutup tabung penyimpanan makanan kucing hingga makanan mencapai berat kurang lebih 50 gram sesuai takaran makanan yang disarankan.

Makanan yang keluar kemudian terdeteksi oleh Loadcell hingga menunjukkan nilai berat di atas 50 gram, setelah berat terdeteksi lebih dari 50 gram maka servo bergerak 140 derajat menutup tabung penyimpanan makanan. Lalu RTC kembali membaca waktu saat itu. Setelah diimplemenasikan kucing dapat makan dengan baik sesuai waktu dan takaran yang telah disesuaikan secara otomatis

\section{KESIMPULAN}

Kesimpulan dari penilitian ini adalah bahwa Alat Pemberian Makanan Kucing Otomatis yang berisikan sensor berat (loadcell) yang memiliki kemampuan mendeteksi berapa berat makanan yang akan dikeluarkan dari tabung. Serta RTC yang mampu menginput waktu makan kucing. Sehingga kucing dapat makan tepat waktu dan sesuai takaran. Dilengkapi juga dengan buzzer sehingga kucing dapat mengetahui waktu makan melalui suara yang dihasilkan oleh buzzer.

Dan dari hasil pengujian yang telah dilakukan terhadap kinerja Alat tersebut menunjukkan bahwa Alat dapat bekerja dengan cukup baik. Dari perancangan aplikasi yang telah dibuat menggunakan Arduino Uno dengan program Sketch dapat memudahkan dalam membuat dan mendesain Alat Pemberian Makanan Kucing Otomatis sehingga Alat menjadi sempurna.

\section{SARAN}

Pada alat ini masih terdapat kekurangan pada sumber daya arus listrik. Diharapkan dapat dikembangkan lagi dengan baterai untuk menghindari apabila terjadi pemadaman listrik, sehingga alat dapat bekerja maksimal meskipun terjadi pemadaman listrik.

Masih terdapat kekurangan pada motor servo yang digunakan, maka diharapkan kepada penelitian berikutnya untuk mencari jenis motor servo lain yang dapat menutupi

\section{DAFTAR PUSTAKA}

Artanto, D. 2012. Interaksi Arduino dan LabView. Jakarta: Gramedia Pustaka Utama.

Handajadi, W, dan Ahmad, S. 2009. "Pembacaan Output Timbangan Digital Jarak Jauh Dengan Menggunakan Pemprograman Visual Basic 6.0." Jurnal Teknologi IST AKPRIND 2.

Kadir, A. 2015. Panduan Mempelajari Aneka Proyek Berbasis Mikrokontroler Arduino. Yogyakarta: Penerbit Andi. 
Limantara, Arthur Daniel, A. I. Chandra, dan S. W. Mudjanarko. 2017. "Manajemen Data Lalu Lintas Kendaraan Berbasis Sistem Internet Cerdas Ujicoba Implementasi Di Laboratorium Universitas Kadiri." Seminar Nasional Sains dan Teknologi 2017. Jakarta: Fakultas Teknik Universitas Muhammadiyah Jakarta. 1-11.

Riza, Muharrir, dan Dedi Satria. 2006. "Perancangan Keamanan Pintu Otomatis Berbasis RFID (Radio Frekuensi Identification)." Helia 2.

Salvana, W. 2008. Pentingnya Menyaga Pola Makan. Jakarta: Gramedia Pustaka Utama.

\section{UCAPAN TERIMA KASIH}

Penulis mengucapkan terima kasih kepada Universitas Harapan Medan khususnya Fakultas Teknik dan Komputer atas dukungan finansialnya pada penelitian ini dan Program Studi Teknik Informatika atas dukungannya dalam keikutsertaan dalam kegiatan ilmiah ini. Penulis juga berterima kasih kepada Dosen-Dosen Teknik Informatika atas diskusinya yang bermanfaat. 